\title{
BOREDOM: A COMPREHENSIVE STUDY OF THE STATE OF AFFAIRS
}

\section{EL ABURRIMIENTO: UN ESTUDIO COMPRENSIVO DEL ESTADO DE LA CUESTIÓN}

\author{
Josefa Ros Velasco ${ }^{1}$ \\ Universidad Complutense de Madrid
}

Recibido: 29/09/2016

Aceptado: 26/01/2017

\begin{abstract}
Resumen: La escasez de literatura es una de las principales quejas hechas por los investigadores del aburrimiento en todos los campos de estudio. Esta afirmación pasa de un estudio a otro sin ser cuestionada, dificultando así la comprensión del verdadero estado de la cuestión. En respuesta, este trabajo demuestra que, de hecho, no es el caso que haya una escasez de literatura sobre aburrimiento; por el contrario, existe una falta de variedad temática y problemas de accesibilidad lingüística. El artículo también refuta la afirmación de que, hasta principios del 2000, había solo unos pocos estudios en aburrimiento publicados cada año. Los resultados se basan en una amplia base de datos que incluye la población total de estudios sobre el aburrimiento y los clasifica según criterios lingüísticos, temáticos y cronológicos.
\end{abstract}

Palabras clave: lenguaje, ocio, literatura, aburrimiento, patología

Abstract: A literature shortage is one of the major complaints made by bore-
dom researchers in all fields of study. This claim passes from one study to ano-

1. (rosvelasco@fas.harvard.edu) Associate in the Department of Romance Languages and Literatures at Harvard University as a RCC Postdoctoral Research Fellow. She holds a PhD in Philosophy at Universidad Complutense de Madrid as a FPU scholar, M.A. in Contemporary Though, and M.A. in Teachers Training. She was visiting researcher at Zentrum für Kultur und Technikforschung at Stuttgart Universität (Germany) as a DAAD (Deutscher Akademischer Austauschdienst) scholar, and at DLA (Deutsches Literatur-Archiv Marbach) as a DLA fellow. She is member of the Research Groups Saavedra Fajardo Library for Hispanic Political Thought at UCM, History and Videogames at University of Murcia, and History and Philosophy of Emotions at CCHS-CSIC. Her main fields of research are Hans Blumenberg's Philosophical Anthropology and Philosophy and Anthropology of boredom. 
ther without being questioned, thus hampering the understanding of the true state of the issue. In response, this paper demonstrates that it is, in fact, not the case that there is a shortage of literature on boredom; rather, there exists a lack of thematic variety and issues of linguistic accessibility. The paper also falsifies the claim that, up until the beginning of the 2000, there were only a few studies on boredom published each year. The results are based on a comprehensive database which includes the total population of studies on boredom and classifies them according to linguistic, thematic and chronological criteria.

Key words: Boredom, Language, Leisure, Literature, Pathology.

\section{Introduction}

Two years ago, prior to writing the first chapter of my Dissertation, I was gathering information about boredom for a review of the state of affairs of the topic. As I read and analyzed the literature, I soon realized that several academic papers on boredom alluded to a shortge of literature and the lack of research interest as being responsible for the lack of understanding of the subject, with some authors justifying the need for their own work on boredom on the basis of this statement. Other such complaints are included in the section devoted to the analysis of these studies. ${ }^{2}$ Criticism of a literature shortage in other areas of boredom analysis is not less prevelant. ${ }^{3}$ The result of this situation, according to Eastwood (2012),

2. See, e.g. the following: 'The existing research on boredom is limited (...)' (O'Hanlon 1981, qtd. in Damrad-Frye and Laird 1989), '(...) review of the extant literature on boredom was relatively unsatisfying and it became clear that organizational researchers know very little about the phenomenon of boredom' (Fisher 1987 and 1991), '(...) studies of boredom are relatively few (...)' (Vodanovich 2003, qtd. in Martin et al. 2006), '(...) little research has been devoted to the topic (...) Research literature relating boredom appears to be both limited and diverse' (Martin et al. 2006), 'Among the few existing studies in which boredom is investigated (...)' (Nett et al. 2011), 'Yet boredom has received far less attention by researchers than emotions such as anxiety, anger, joy or interest. (...) there is a clear lack of research on the boredom experienced (...)' (Pekrun et al. 2010), '(...) limited research has been focused in this construct [boredom]' (Vodanovich and Watt 1999).

3. Some states are, e.g.: 'Areas covered by this literature are wide-ranging, and no particular aspect has received sustained attention. (...) A noticeable gap in research literature is any evidence of ways to overcome boredom' (Martin et al. 2006), '(...) little systematic research has examined how strategies to cope with boredom are structured and classified' (Vodanovich 2003, qtd. in Nett et al. 2010), '(...) studies on the boredom experienced in achievement settings are largely lacking' (Pekrun et al. 2010), 'Limited work, however, has been devoted to investigating the association between boredom and psychological and physical health symptoms' (Sommer and Vodanovich 2000), 'The measurement of boredom has received relatively little systematic attention in the literature' (Vodanovich 2003), 'Research examining the

Thémata. Revista de Filosofía №56 (2017) pp.: 171-198. 
is that 'the scientific study of boredom remains a relatively obscure niche and boredom itself is still poorly understood'.

I was surprised to find that complaints about a literature shortage and lack of research interest were always very similar. They followed the same pattern and seemed to be copied from one paper to another. At first I, as my predecessors, was tempted to follow the prevailing trend and insert a sentence into my dissertation suggesting that the study on boredom had been neglected given the literature shortage. However, I then realized that I could not take such an unequivocal claim for granted without first finding out if it was true. As such, I decided to investigate whether or not we really were facing a problem in terms of a lack of research and interest in boredom, finding it to be untrue.

In The Conquest of Happiness (1930), Bertrand Russell argued that boredom, as a factor in human behaviour, had received far less attention than it warranted. Henceforth, many authors have uncritically repeated this statement and continue to do so even to this day; for example, the quote from Smith (1981), explaining that there was only a single article about boredom published per year from 1926 to $1980 .{ }^{4}$ To this we may add the more recent work of Leong and Schneller, in which they state that there were around four articles per year appearing by $1993 .{ }^{5}$ Belief in a shortage of literature has come to be seen as the undisputed final word on the matter. Thist myth is then transferred from the background of one study to another. Thus, no one has considered the existing body literature on boredom, its distribution in different languages and thematic areas,

work outcomes associated with trait boredom is somewhat limited' (Bruursema 2007), '(...) shortcoming of boredom research in work environments (...)' (Kass et al. 2001), 'Few have explored this topic in the lives of people with physical disabilities (...)' (Lee et al. 1999).

4. Smith, R., Boredom: A review, Human Factors, 23(3), 1981, 329-340; 'Articles concerning boredom averaged less than one paper per year during the review period'. 'In a review of the psychological and psychiatric studies of boredom from 1926 to 1980, Smith (1981) found that articles on this subject averaged less than one per year' (Farmer and Sundberg 1986), 'For instance, Smith (1981) estimated that an average of one article per year was published on boredom' (Vodanovich and Watt 1999).

5. 'Smith (1981) reports an average of less than one research publication on this topic per year. A review of Psychological Abstracts reveal an increase in journal publications focousing on boredom to roughly 4 per year from 1983 to the present; however, about one-third of these articles are conceptual or theoretical and do no involve research on boredom. A better understanding of boredom is clearly warranted' (Leong and Schneller 1993). See also: 'A recent review of Psychological Abstracts has raised this figure to approximately four per year' (Leong and Schneller 1993, qtd. in Vodanovich and Watt 1999).

Thémata. Revista de Filosofía N56 (2017) pp.: 171-198. 
nor followed the temporal trends in a methodological way in order to check whether such assertions correspond to reality.

In light of this, I took the decision to ascertain for myself whether or not we really faced a problem of disinterest in boredom that was reflected in a shortage of literature. After discovering that neither existed - a literature shortage nor a lack of interest -, I wanted to analyze the reasons why scholars had noted such a sense of disinterest in research on boredom. Perhaps the study of boredom had been held back because it itself bored researchers? Unequivocally not. In fact, on the contrary, the phenomenon has aroused the interest of scholars for centuries. What is more, since the beginning of the twentieth century, it has also become a matter of serious discussion in the physical sciencies, for example in psychiatry. Most likely, then, it is the result of a lack of information and accesibility. There is both ample literature and interest, but papers produced on boredom are neither particularly accessible nor diverse. Most of the literature and papers belong to the same niches of study (disciplines such as psychiatry, psychology, and so on) and almost a half of them are inaccessible to many of us due to the language in which they are written.

I considered it very important to share my discoveries with future researchers on the subject by publishing a paper so that they do not fall into the same trap as I was about to. In order to develop this further, I hypothesize that it is not true that there exists shortage of literature on boredom; rather there exists a lack of thematic variety and availability in accessible languages. I also disagree with the statement that until the 2000 s there have only been a few studies on boredom published per year. The following steps were taken in order to test my hypothesis: (1) establishing the total population of academic studies on boredom; (2) classifying the individual studies by language; (3) classifying the individual studies thematically; (4) classifying the members of the population according to thematic area in the language to which they belong; (5) classifying the population chronologically; and (6) classifying the members of the population chronologically according to the thematic area to which they belong to see the historical trend.

In doing so, we see that there exists ample literature on boredom, but thas it is written in some languages which are inaccessible to the general public; moreover, the thematic variety is very narrow. Nonetheless, we will demonstrate that interest in the study of boredom in fact first arose over two centuries ago and has increased over time. The literature shortage and lack of interest in researching boredom can no longer be used as the justification for further projects. The results of the analysis allow us to set out a complete picture of the state of affairs in research into boredom that will light the way for future researchers to develop their work on a firm 
basis, thus avoiding the mistake of repeating the afore mentioned claims of a literature shortage and lack of interest in the subject.

\section{Methodology}

Step one (1): ascertaining the total population of academic studies on boredom. We used the online search tool Google Scholar. Through this web application, we were able search a large number of works on boredom, including studies, doctoral dissertations, books, abstracts and papers from several disciplines. We also had take into account that studies of boredom have been written in various languages, all of which form part of the total population regardless of the language in which they are written. However, from the very start, we recognised the inherent limitations of this tool that made it impossible to unearth each and every study ever written on boredom. What we could feasibly hope to achieve was to highlight those which contained "boredom" in the title and, from there, regardless of the fact that there likely exist many more studies which do not employ the word in their title and therefore go unnoticed, verify our hypothesis that complaints of bibliographic scarcity were unfounded. Thus, we entered the word "boredom" in the search box of Google Scholar in the different languages this application allowed. From these searches, we obtained a list of results that included the total number of works in different languages that contained in the title the word "boredom" in the Google Scholar database.

Step two (2): classifying the members of the population according to the language in which they were written. Once the list containing the population of academic studies on boredom had been obtained, we classified the members of the population according to the language in which they were written. We elaborated different lists for each language that yielded results - there were no studies on boredom written in many of the languages checked. Then, those lists in which there were one hundred or more results $(\geq 100)$ were taken into account as the 'Classifiable Population'; this constitutes the sample with which we worked through the rest of steps. Meanwhile, those lists which contained less than 100 items $(<100)$ were grouped together into a single group called 'Not Classifiable Population', which were not taken into account in some parts of the study due to their inaccuracy or unrepresentativeness.

Step three (3): classifying the members of the population (classifiable population) according to the thematic area. We created categories as required, considering that a thematic was sufficiently representative to constitute a category if there was more than one $(>1)$ result that could be

Thémata. Revista de Filosofía N56 (2017) pp.: 171-198. 
classified under the same name. The other items of the classifiable population - those that could not be classified according to existing categories as a result of being a singular (1) result - were compiled in a separate category called 'Not Classified'. The thematic areas created were as follows:

a) Art and Media (AM): studies in which boredom is addressed to, related to or focused on any of several artistic disciplines, such as music, painting, theatre, cinema, comics, photography, creativity in advertising and the staging of media communication, among others. E.g., Priest 2011, Sibayan 2014, Mallory 2003, Byor 1975 or Gombrich 1999.

b) Philosophy and Theology (PHT): studies in which boredom is addressed to, related to or focused on different philosophical (existentialist, phenomenological, metaphysical, etc.) or theological issues. E.g., Bargdill 1998, 2000, Bigelow 1983, Clive 1965, MacDonald and Holland 2002 and Raposa 1999.

c) Physics (PHY): studies in which boredom is addressed to, related to or focused on issues around space and time from the scientific discipline of physics. E.g., Anderson 2004, Vodanovich and Watt 1999.

d) General (G): studies in which boredom is approached from a general and superficial perspective without being related to any particular field. E.g., Smith 1981, Scitovsky 2000, Perkins 1981 and Hopkins 1980.

e) Gerontology (GT): studies in which boredom is examined within the gerontological discipline. E.g., Strahan 1980, Stagner 1975 or Bromberg 1981.

f) Labor (LA): studies in which boredom is discussed in relation to the problems of working life (lack of motivation, leadership, etc.). E.g., Abdolahi et al. 2011, Cronon 2012 or Fisher 1991, 1987.

g) Literature (LI): literary studies in which boredom is the main theme as a narrative or as a literary movement. E.g., Weinberg 1984, Yamamoto and Ishikawa 2010 and Tucker 2007.

h) Neurocognitive Sciences $(\mathrm{N})$ : studies in which boredom is analyzed in terms of the biological mechanisms underlying cognition, with a specific focus on the neural substrates of mental processes and 
their behavioural manifestations. E.g., Artino and Stephens 2007, London and Monell 1974 and Merrifield 2014.

i) Oncology (O): studies in which the role of boredom in the experiences or lives of cáncer patients is analyzed. E.g., Theobald et al. 2003, Inman et al. 2003 or Passik 2003.

j) Academic (AC): studies in which boredom is addressed to, related to or focused on issues in the academic world and pedagogy. E.g., Acee et al. 2009, Harrison 1984 or Nett et al. 2010.

k) Political, Economic and Military (PEM): studies in which boredom is approached in relation to the political, economic and military issues. E.g., Rubin 2009, Bills 2003 or Hancock and Krueger 2010.

I) Psychology, Psychiatry and Therapy (PPT): studies in which boredom is addressed to, related to or focused on the issues surrounding the psychological and psychiatric disciplines and the treatments and therapies offered in both fields. E.g., De Chenne 1988, Binnema 2004 or Fenichel 1951.

m) Computational Sciences (C): studies in which boredom is analyzed in relation to computers, computing and its application to computer systems. E.g., Rakoff 2001 or Bolland and Emami 2007.

n) Leisure (LE): studies addressing boredom in terms of the phenomenon of leisure and the use of leisure time. E.g., Barnett 2005 or Iso-Ahola and Weissinger 1987.

o) Measurement Techniques (ME): studies that focus on the analysis of the different techniques for measuring boredom. E.g., Ahmed 1990 and Farmer and Sundberg 1986.

p) Society, Ethnology and History (SEH): studies in which boredom is addressed to, related to or focused on issues surrounding social, ethnological and historical phenomena. E.g., Barbalet 1999, Mains 2007 and O'Farrell 1982.

q) Zoology (Z): analysis of boredom in the animal kingdom. E.g., Hamilton 1999 or Wemelsfelder 1993.

r) Female (FE): studies on the phenomenon of boredom and the female gender. E.g., Núñez 2000. 
s) Sex and Relationships (SRP): studies that analyze boredom in sexual, interpersonal and marital relations. E.g., Dym and Glenn 1994 and Ohlendorf 2012.

t) Paleontology and Anthropology (PAN): studies that take into account boredom as a means of interpreting the life of our ancestors. E.g., Bilz 1971.

u) Not Classified: studies on boredom that can neither be classified in any of the above categories nor permit the creation of a new category because of the number of its exponents. E.g., Köster et al. 2007, Fahmy and Noble 1981 and Charlton 2008.

Step four (4): classifying the members of the population (classifiable population) according to their thematic area in the language in which they are written. We classified the contents of the different lists of the classifiable population (languages that yield a hundred or more than one hundred results in our search) separately according to their thematic area. As a result, we obtained different lists for the different languages, in which their members were grouped into the thematic categories. Thus, the subpopulation of each language was classified according to its thematic area in order to observe the predominance of each category in each language.

Step five (5): classifying the population (classifiable population) chronologically. We organized the classifiable population chronologically including only the years in which we could find some result. Those results which were not dated were classified separately as 'Not Dated'.

Step six (6): classifying the members of the population (classifiable population) chronologically according to thematic area. We organized the classifiable population chronologically to analyze the number of studies published on boredom each year in each thematic area. Those results that were not dated were classified separately as 'Not Dated'.

The whole recopilation of data can be found in a series of tables locatable in the following link https://goo.gl/Go8VaZ not to exceed the properly space of this paper.

\section{Results}

Step one (1): ascertaining the total population of academic studies on boredom. The total population of academic studies on boredom which we found with the online search tool Google Scholar was 2,878. The languages that yielded results when we entered the relevant word for 'Bore- 
dom' in the search box were: German, Arabic, Spanish, Catalan, Korean, Croatian, Danish, Slovak, Slovenian, Esperanto, Finnish, French, Greek, Hausa, Hebrew, Dutch, Hungarian, Indonesian, English, Icelandic, Italian, Javanese, Norwegian, Polish, Russian, Serbian, Swedish, Thai and Turkish. The results of these searches made up 100\% of the population.

Step two (2): classifying the members of the population according to the language in which they were written. We considered as our 'Classifiable Population' only those languages whose search yielded a hundred or more $(\geq 100)$ items. Those languages were Spanish, Chinese, French, English, German and Japanese and were distributed as follows: German 415 results (15.66\%), Spanish 138 results (5.20\%), Chinese 560 results (21.14\%), French 319 results (12.04\%), English 986 results (36.54\%) and Japanese 231 (8.72\%). These added up a total of 2,649 studies (92.04\%). The rest of the studies in other languages, included in the category 'Not Classified' totalled 229 titles (7.95\%). From this moment on, we only took into account the sample of the population consisting of the members of the languages that yielded a hundred or more $(\geq 100)$ items; i.e. the classifiable population.

Step three (3): classifying the members of the population (classifiable population) according to the theme. We organized the classifiable population of 2,649 studies into the following thematic areas: Art and Media (202 results), Philosophy and Theology (168), Physics (15), General (176), Gerontology (24), Labour (168), Literature (354), Neurocognitive Sciences (36), Oncology (5), Academic (340), Politics, Economy and Military (122), Psychology, Psychiatry and Therapy (367), Computational Sciences (69), Leisure (136), Measurement Techniques (29), Society, Ethnology and History (203), Zoology (20), Female (9), Sex and Relationships (18), Paleontology and Anthropology (5) and Not Classified (183). The most popular field in general was Psychology, Psychiatry and Therapy, followed by Literature and Academic.

Step four (4): classifying the members of the population (classifiable population) according to theme in the language in which they were written. English: The English subpopulation consisted of 986 studies (36.54\%) which were distributed in the following thematic areas: AM (41), PHT (55), PHY (10), G (41), GT (11), LA (95), LI (90), N (36), O (5), AC (113), PEM (53), PPT (206), C (23), LE (59), ME (27), SEH (77), Z (18) and NC (26). The most popular field in the English subpopulation was Psychology, Psychiatry and Therapy. German: The German subpopulation consisted of 415 studies (15.66\%) distributed as follows: AM (38), PHT (50), G (38), GT (4), LA (24), LI (70), AC (42), PEM (17), PPT (31), C (2), LE (39), SEH (37), PAN (3), SPR (4) and NC (16). The most popular field in the German subpopulation was Literature. French: The French subpopulation consis-

Thémata. Revista de Filosofía №56 (2017) pp.: 171-198. 
ted of 319 studies (12.04\%) distributed in the following thematic areas: AM (25), PHT (24), PHY (2), G (33), GT (2), LA (4), LI (83), AC (36), PEM (6), PPT (63), LE (4), SEH (26), SPR (3) and NC (8). The most popular field in the French subpopulation was Literature. Chinese: The Chinese subpopulation consisted of 560 studies $(21.14 \%)$ which were distributed in the following thematic areas: AM (57), PHT (7), G (37), LA (28), LI (65), AC (117), PEM (33), PPT (37), LE (18), SEH (27), SPR (11), GT (4), C (38), FE (4), ME (2) and NC (75). The most popular field in the Chinese subpopulation was Academics. Japanese: The Japanese subpopulation consisted of 231 studies (8.72\%) distributed as follows: AM (24), PHT (15), G (21), LA (11), LI (27), AC (14), PEM (13), PPT (10), LE (6), SEH (26), GT (3), C (3), FE (3), PAN (2), Z (2) and NC (51). The most popular field in the Japanese subpopulation was Literature, although the result was not relevant due to the high number of items classified in the 'Not Classified' category due to their ambiguity. Spanish: The Spanish subpopulation consisted of 138 studies (5.20\%) distributed in the following thematic areas: AM (17), PHT (17), PHY (3), G (6), LA (6), LI (19), AC (18), PPT (20), LE (10), SEH (10), $\mathrm{C}$ (3), FE (2) and NC (7). The most popular field in the Spanish subpopulation was Psychology, Psychiatry and Therapy (see Table 1).

Step five (5): classifying the population (classifiable population) chronologically. The total population of academic studies published each year are available for examination the link given above (see Table 2). At the bottom of the Table 2 there is a separate box titled 'Not Dated' in which we organized the studies of the classifiable population for which the date of publication was unknown. It is not true that from 1926 to 1980 there appeared one article per year. We may draw attention to years like 1937, when there was a total of 3 studies, or 1939, when there were 4 . Subsequent years show a gradual increase: 4 studies in 1948, 5 in 1950, 10 in 1951, 5 in 1952, 7 in 1953, 6 in 1959, 8 in 1962, 9 in 1965 and from 1966 to 1969 a total of 45 studies. We find a total of 178 studies published in the 70 s. This demonstrates that the statement made by Smith 1981 is untrue. From 1926 to 1980 (54 years) a total of 326 studies were published. Moreover, in the years before 1926, we see a total of 51 studies in 222 years. However, these are rarely considered by researchers. In the same way, the claim by Leong and Schnell (1993) that there were 4 papers per year in 1993 does not correspond to reality. In 1993 alone, we find a total of $36 \mathrm{stu}$ dies and the number continues increasing in subsequent years reaching 119 items in 2013. To sum up, it is not true that there was little attention to boredom, neither in the past nor the present.

Step six (6): classifying the members of the population (classifiable population) chronologically according to the theme. The total population of academic studies published each year distributed according to thematic 
area are available for examination in Table 2. At the bottom of the table there is a separate box titled 'Not Dated' in which we organized the studies of the classifiable population for which the date of publication was unknown. We can confirm that the chronological trend has played in favor of the psychological and psychiatric issues. ${ }^{6}$

\section{Discussion}

The study of boredom finds itself in a paradoxical state; one which makes its definition and explanation difficult from the multiple disciplinary perspectives from which it is drawing interest. As it stands, researchers consistently decry the paucity of the existing bibliography with regards to the analysis of boredom, and a perceived lack of interest in resolving the conflict that this creates. Experts point to both problems as reasons that it still remains impossible to understand exactly what boredom is and, thus, justify the need to publish their own work. Using our method to conduct a survey of the existing literature, we determine that the population of academic studies on boredom is 2,878 . This is a considerable total when one considers the time it would take a researcher to cover this body of literature.

In this study we have taken into account only those works which were retrieved by our chosen search tool and were published in the eighteenth century or later. While it is certainly true that thinkers in Ancient Greece did not leave much written evidence of boredom, we can nonetheless find some brief and superficial allusions that might be seen to refer to boredom. Examples of this can be found in the The Iliad (Book 24, passage 403), in Pythian (passage 81-83) by Pindar, in the fragment 804-808 of Iphigenia in Aulis by Euripides, and Plato's Symposium (section 173c). As Toohey (1988) argues, 'It would be incredible to maintain that Greeks did not feel such an emotion'. Let us suppose that it were in fact something that seriously preoccupied the Greeks (Martin et al., 2006). Perhaps they did not make a more profound statements on boredom simply because, as Leslie (2009) ventures, it made no public contribution to the formation of one of the fundamental cornerstones of their civilization: the obligation to participate in political life by cultivating their own virtues in this manner.

6. Also, there are some extra tables in which we can find a classification of the members of the population (classifiable population) chronologically according to the language in which they were written (Table 3), and of the members of the population (classifiable population) chronologically according to thematic are in the language in which they were written: Tables 4 (English), 5 (German), 6 (French), 7 (Chinese), 8 (Japanese) and 9 (Spanish). All of them have not been included in this paper as a matter of lenght.

Thémata. Revista de Filosofía N56 (2017) pp.: 171-198. 
It was through the foundation of Epicureanism and its extension to Roman Greece that people acquired positive notions of free time and boredom. The Epicurean ethic maintained, in contrast to its antecedents, that virtue lay in liberation from political matters in order to gain time that allowed for idleness, the direct consequence of which was boredom. The Stoicorum Veterum Fragmenta (SVF) by Hans von Arnim demonstrates one of the earliest uses of the word "boredom" outside of the few salvaged fragments from the work of one of Epicureanism's greatest exponents, Metrodorus of Lampascus (Papyrus Epicurei, Fragment 831).

The first serious considerations of boredom appeared in Rome during the first century $\mathrm{BC}$, in relation to an uncomplicated and incipiently spiritual form of "horror loci" that would later be found in the works of thinkers like Lucretius (On the Nature of Things, passage 1060-1067), Horatio (Epistles, 8, 11) and Seneca (Epistulae morales ad Lucilium, epistles 24, 40, 70) (Toohey 1988). After Seneca, the consolidation of the notion of boredom as being linked to a fear of death was established definitively with the emergence of Christianity and the subsequent period of cultural rebirth in the fourth century, during which we witness the birth of the concept of "Acedia". The rise of Christianity marks an unprecedented moment in which responsibility for the self falls into the hands of pastoral powers, the priesthood, institutions and ecclesiastical hierarchies. It therefore ought to be a period of great boredom. Demonstrations of this appear in the scornful descriptions of boredom in the Holy Scriptures (Proverbs), as well as Essays by Montaigne, Saint Augustine's Confessions (VIII), Evagrius Ponticus's Antirrhetikon, Casiano's Institutions, Saint Thomas' Summa Theologiae (II-II, 35) and the eponymous Spiritual Exercises of Ignatius of Loyola. Protestantism later devolved the authority and responsibility for selfdisposal to the individual and promoted literacy and the idea of universal equality in the community (Leslie 2009). The modern phenomenon of boredom must be understood in the context of this new thirst for individuality.

Boredom as we experience it today - as a sort of recognition of the absurdity of existence - was not experienced with much frequency or across a large spectrum of people until the point that leisure and wealth began to grow (Conrad 1997, Musharbash 2007). Similarly, strictly-speaking it did not even appear as a concept until the eighteenth century as an expression of metaphysical despair and socio-political impotence (Antón 2012). It is at this point that we begin to pick up the trail with the first of the studies which comprise our database. From the eighteenth century onwards, boredom appears with increasing regularity in the philosophical sphere with the emergence of the writings of Voltaire (The Age of Louis 
XIV), Rousseau (Emile, or on Education) and Kant (Anthropology from a Pragmatic Point of View).

It is true, however, that language may have played a limiting role in many incidents. Although most of the literature on boredom is published in English (a total of 986 works), much of it exists in languages barely accessible to the general public, such as Chinese (560 studies) and Japanese (231 studies). Perhaps this has been one of the major reasons why researchers have complained about a lack of literature on boredom. Moreover, the researchers who complain of a bibliographic scarcity do not seem to be taking into account the different formulations and transformations of the term that have shaped boredom throughout history. Beyond its formulation as 'acedia' and its Christian implications, it is in the eighteenth century that we begin our journey with the first appearance of the English word "boredom" in print in approximately 1766 (Healey 1984). During the Renaissance, "acedia" was replaced by the term "melancholy", an emotion that also affected the aristocracy, imbued instead with a notional relationship to sickness and wisdom (Musharbash 2007).

Similarly, by the twelfth century an alternative to "acedia" had already come into use in France: "ennui". Taken from the Latin "enodiare", it refers to a hatred for one's own life (Martin et al. 2006). The use of the French word "ennui" filtered into English at the end of the seventeenth century, gradually giving rise to what would later become known as the "English disease" (Toohey 1988; Antón 2012). European poets and commentators dedicated some of their most anguished lines to the subject of boredom, as in The Life and Letters of John Donne and Pascal's Pensées (Thoughts). From this moment on, tedium has become an important subject in both French and English literature as a symbol of sophistication amongst the social elite.

The moment at which boredom took hold of the philosophical and literary production was the in nineteenth-century in Europe (Martin et al. 2006). Boredom, as Svenden (1999) points out, was a privilege of the modern man, as Romanticism pondered on the massive transformations that had begun to reveal themselves the previous century. A multitude of thinkers throughout the West grappled with this most complex of emotions, pointing to a precursor in the well-known contemporary "pathology" in what was known as the "English Disease" (see Lyrical Ballads by Wordsworth and Coleridge or Don Juan by Lord Byron (Don Juan) (Peters 1975), the "Sturm und Drang" (see Schiller (The Maid of Orleans and Fiesco), Kleist (The Schroffenstein Family), Büchner (Leonce and Lena, Danton's Death and Lenz), Novalis (Hymns to the Night), Hölderlin (The Death of Empedocles, acts 1-3) or Heine (Conditions in France and Book of Songs), as representatives of capturing the general sensation of the decadence of

Thémata. Revista de Filosofía №56 (2017) pp.: 171-198. 
the age in literature (Völker 1975), and in philosophy see Goethe (Schriften zur Naturwissenschaft, The Sorrows of Young Werther, From my Life: Poetry and Truth, Italian Journey, Kampagne in Frankreich, Sonette XV, Götz von Berlichingen mit der eisern Hand, to name only a few), Schopenhauer (The World as Will and Idea, Zur Philosophie und Wissenschaft der Natur, Parerga and Paralipomena), and Nietzsche (Twillight of the Idols, On Truth and Lies in a Nonmoral Sense, The Antichrist, The Gay Scien$c e$ ), among others), or the "mal de siècle" (see Chateaubriand (Memoirs from Beyond the Tomb), Baudelaire (Flowes of Evil), Durkheim (Suicide), Flaubert (Madame Bovary), Verlaine (The Damned Poets, Songs Without Words) and Mallarme (Poems). The writers of this period are crucial not only to understanding the way in which transformations in the perception of boredom came to a head, but also as testimony to mistakes made by researchers in their allegations of a lack of interest in the topic.

The idea of boredom that devastated European civilization, turning its subjects into sleep-walkers that wandered around unconscious in search of that which would permit them to regress to the state of wild animals, reached as far as Norway, Sweden, Denmark and, of course, emotionally-repressed Russia. In these countries the population had the now-familiar experience of the emotion of boredom, perhaps with the exception of those few who continued to work in forced labour (Kreisel 2006) (see Henrik Ibsen (Peer Gynt. A Dramatic Poem, Hedda Gabler); August Strindberg (Röda Rummet, Hemsöborna. Skärkarlsliv, Giftas); Søren Kierkegaard (Either/Or, The Concept of Anxiety, Repetition, The Sickness Unto Death, On the Concept of Irony with Continual Reference to Socrates); Dostoyevsky (Prision Life in Siberia, White Nights, The Gambler, Notes from the Underground, Crime and Punishment) and Leo Tolstoy (Anna Karenina, War and Peace, The Kreutzer Sonata, Family Happiness, Father Sergius, Resurrection, The Kingdom of God is Within You).

The multitude of texts that have been dedicated to boredom over the course of history in its different linguistic formulations forces us to consider that it refers to a sort of intercultural apex, an emotion that affects man from the greatest depths of his being. From the Blumenberg's view (2006), boredom might be considered as the anthropogenetic state in which representatives of all cultures that have been encountered, are encountered and will be encountered as it is an inherent part of the human being. The feeling of taedium affects all of us and not only configures our character, but also our habits and the world of our design in which we find ourselves immersed.

Perhaps these sorts of conceptions of boredom and the literature in which they have been brought to light have passed by unnoticed those that protest a shortage of literature and interest because the study of bo-

Thémata. Revista de Filosofía N56 (2017) pp.: 171-198. 
redom has focussed mainly on specific thematic areas since the twentieth century. For example studies of boredom and its implications for literature (354), academic issues (340) and the clinical dimension including psychological, psychiatric and therapeutic works (367). Other areas of study are beginning to show interest in the phenomenon of boredom but, as yet, we can say there is little literature emanating from disciplines such as anthropology or paleontology. Here, we may ask for more attention to be paid to the topic in these areas of study so that we may obtain a better understanding.

In the first half of the century it is possible to detect an increase in the use of the word boredom, reflecting an expansion of the penetration of boredom in modern society. The literary, philosophical, sociological and psychological writings of the time are a clear demonstration of the progressive acceptance of the increased usage of the concept. Richard Kuhn's (1976) phenomenal diagnosis superb assessment argues that in the twentieth century boredom was not merely one recurring theme amongst many, but the dominant one; an persistent obsession that enmeshed itself in the works of the majority of contemporary writers throughout the world. Perhaps the greatest literary production comes from German language, from novelists such as Mann (Buddenbrooks, Royal Highness, Little Mr Friedmann, The Magic Mountain), Fontane (Effi Briest, Trials and Tribulations, Jenny Treibel), Musil (The Confusion of Young Törless) and Kafka (Diaries). During the twentieth century, the literary production revolving around boredom spread without concern for borders, moving from Germany and Austria towards Spain (Unamuno, Mist) by way of France (Valéry, Variété, Dance and The Soul, Mon Faust) and Portugal (Fernando Pessoa, The Book of Disquiet). This phenomenon, which had captivated intellectuals since the previous century, began to pose a challenge to the study of sociology for thinkers such as Deleuze (Postscript on the Society of Control), Simmel (Philosophy of Money, Introduction to the Science of Ethics), Durkheim (The Division of Labour in Society, Suicide) and Kracauer (The Mass Ornament). In addition, one of the most representative battlefronts in the examination of the social and historical conditions of complex boredom associated with sociology and likewise with the philosophy of the era through critical theory and critical ideological discussion was the Frankfurt School (Benjamin, The Arcades Project, Adorno and Horkheimer, Dialectic of Enlightenment). Taking a more philosophical approach, boredom began to capture the imagination of the existentialists such as Sartre (The Transcendence of the Ego), but also Heidegger (The Fundamental Concepts of Metaphysics).

In the centre of a landscape in which boredom carried with it more and more problems and difficulties for people at a time of adaptation to a complex society, the discipline of psychology will soon gradually enter the 
scene to offer a first examination of the introspective capacity of boredom. Boredom did not begin to be studied seriously by psychologists until the final decades of the twentieth century. Some of these works concentrate on defending the existence of a propensity to boredom on the part of individuals generated by the intensification of work and the new tendencies of the era. However, the majority of these focus on the existing relationship between boredom and anxiety, gambling, aggression and eating disorders, amongst other pathologies. The affective, cognitive and motivational aspects of boredom as a constructed emotion have been understood as a threat to the individual's perception of meaning and their capacity to re-establish meaning on that which surrounds them. Unlike sociologists, who would understand boredom as a constructed emotion, psychologists have conceived of it as a passing emotion and a psychological trait. Perhaps the first of these modern works on boredom in this context are those of Emile Tardieu (L'ennui: Étude Psychologique) and Theodor Lipps (Guide to Psychology).

At the beginning of the twenty-first century, when specialists appear to have forgotten the historical precedents of the phenomenon and decry a lack of interest in and paucity of the bibliography on the subject, the first technical scientific definitions of boredom begin to emerge alongside psychology and psychiatry which have facilitated the perception of the phenomenon as an absolute and incomprehensible reality. Boredom arose as a subject of scientific investigation as a result of industrial psychological examinations of workplace efficiency (Munsterberg 1913). Since then, the study of boredom has been carried out across a wide range of unrelated fields, occupying a predominant place in the work carried out in disciplines related to the field of mental health. Among these there exists a lack of consensus with respect to the origin and nature of boredom, as well as its causes and its consequences. At the end of the twentieth century and the beginning of the twenty-first, we find ourselves confronted with total confusion and lack of agreement over a phenomenon so extremely common that it has become an unfathomable task. As if caught in a vicious cycle, this situation impedes the development of better tools for the study, measurement and evaluation of boredom that might lead to a genuine understanding of the phenomenon (Vogel-Walcutt et al. 2012).

On examination of the existing bibliography on the topic we find that, complicating things yet further, a split has been established between two variants of boredom: the simple and the complex. Simple or situational boredom is defined as the most common state of taedium which is temporarily experienced by all human beings (Toohey 2011). Complex Boredom, for its part, is conceived as a transcendental form of taedium that many would define as profound and existential in the manner of Roman 
writer Emil Cioran in Histoire et Utopie (see also Todman 2003, Healy 1984). Whilst this second form of boredom has resulted in voluminous work in books and articles, precious little attention has been paid to "simple" boredom which is seen as trivial (Toohey 2011).

Following on from the above, work on boredom - principally of the complex variety - has brought to light its association with a particular type of malady or difficulty. From this perspective, it has pushed forward the idea that boredom is a problem that affects individuals in regards to their personal and social development and is an issue that needs to be resolved. Within these parameters, the affliction of boredom occurs inside the subject like a pathology or a disorder, even taking the form of a chronic illness with grave psychosocial consequences (Eastwood et al. 2012) and mental health problems (German and Latkin 2012; Bergler 1945). It was at the beginning of the twenty-first century that complex boredom, considered personal problem, came to represent a question of scientific and clinical interest; that is, to be analyzed in terms of its neurological and psychological conditions, despite the fact that hardly anything is known of its cognitive or neural basis (Eastwood et al. 2012; Danckert and Allman 2005).

Today, boredom is thought to arise as a consequence of a disconnect between the patient and his environment that persists despite changing external conditions. These are caused by pathologies of boredom such as the pathology of chronic boredom, the disorder of a propensity towards boredom or the problem of subjective perception of boredom. Otherwise, it is seen as a corollary of other pathologies, such as an inability to clarify one's own desires, a distorted perception of time, an excess or lack of self-awareness, an inability to find meaning in existence, attention deficit disorder and hypochondria, or perhaps even many of these at the same time. As a result, a large part of the extant bibliography regarding complex boredom as a problem affecting individuals is geared towards treatments of it as a pathology. Specialists in psychoanalysis and existential philosophy (Martin et al. 2006) have learned to deal with boredom and teach others how to get to grips with it in order that they might prevent or tackle it (Goffman 1959; Conrad 1997). Our era, more than any other, has seen the proliferation of innumerable antidotes to the evil of boredom (Retana 2011), be that through the implementation of strategies of confrontation or avoidance (Nett et al. 2010). For their part, psychiatric professionals consider boredom as an experience that lacks the sort of qualities that would justify treatment as a common pathology like depression or stress (Butler et al. 2011), since it plays a definitive role within psychotic disorders as a result of its neurotic implications (Bergler 1945). For some, the treatment of boredom will necessitate the genetic location of the illness in 
order to allow for an intervention at the neurological level (Bergler 1945). That which most interests researchers in the context of complex boredom as a personal illness is the consequences that emerge from suffering it (Tilburg and Igou, 2011; Martin et al. 2006; Vodanovich and Watt 1999). However, this predominance of psychological and psychiatric perspectives in the study of boredom serves to demonstrate that there indeed exists great interest in the phenomenon and that the existing literature is not much less abundant.

From other disciplines, which contribute to demonstrate this interest, have understood boredom as a causal reality that causes effects necessarily to whom experiences it and that not necessarily respond to a dysfunctional but creative profile. As an experience that triggers anxiety and agitation (cf. Tilburg and Igou, 2011: 181-194), and perhaps even something like nervousness ( $c f$. Fenichel, 1951), boredom, detached from the complexity of the mental disease, appears as a cause of the innovation cycle, as discontent with the above because "when we are bored there is something of the context that we are rejecting» (Retana, 2011: 183), which organizes the search for the novelty as a reaction to the environment. It is a symptom that instigates moments of experimentation and expansion (Parreño, 2013; Moravia, 1999), including a critical element, an expression of deep dissatisfaction (Svendsen, 2006). Taking up the words of Toohey (2011: 185), we note that boredom has other positive characteristics as well. Scholars such as Dr. Peter Toohey has pointed out that the potential character of boredom meets an adaptive function among members of our species - following the psychologist Robert Plutchik and the neurologist Antonio Damasio. As Toohey, the German philosopher Hans Blumenberg has seen the phenomenon of boredom under these anthropological categories. He has tried to understand the scope of the anthropogenetic adaptive function that resides on the driving force of boredom. Boredom meets an adaptive role in stimulating change that keeps our interest and forces us to constantly retraining (Blumenberg, 2011).

Finally, it is true that much of this literature has the added problem that it is difficult to access as it is either no longer available or very difficult to find. This was even more difficult for researchers in the past for whom this technology did not exist. These are very complicated issues which make it difficult to address the variety of literature on boredom but, as we suggested, this does not mean there is a limited bibliography. The use of Google Scholar as search tool implies certain limitations as it is quite likely that not all existing works on boredom are registered in its database. In any case, this does not contradict our conclusions as we would be leaving out some studies which would merely confirm that it is untrue to claim that there is a shortage of literature on boredom. Google 
Scholar does not provide access to all studies, merely their bibliographic data. Thus, there were a minimum number of cases in which we classified a study in a thematic area by its title, abstract, keywords and even by the magazine or publisher in which it appeared. Despite these limitations, it was essential to gather a complete knowledge of the state of affairs of research into boredom that will provide future researchers with a means of developing their work on a sound basis.

Thus, our paper represents a task that had never been performed before, from which we are able to observe the state of affairs of the study on boredom today with reliable and comparable data. In doing so, we have not only demystified the claim about a literature shortage, but also the idea that boredom was not studied until recently. We have drawn a clear map of the landscape of studies on boredom paying attention to the different languages in which they have been written, their various thematic areas and their temporal trends. Thanks to this effort, researchers of boredom will be able to discuss the state of the question with clear frame of references. This project is a starting point for further research and serves as a call for more attention from other disciplines that can certainly shine a light into the darkest recesses of the phenomenon of boredom ${ }^{7}$.

\section{Bibliography}

Abdolahi, B., Damirchi, G. V., Ganjeh, H. 2011. "Surveying of Job boredom proneness effect on Job Satisfaction and Job Involvement, Case study: Ardabil province SMEs". Interdisciplinary Journal of Contemporary research in Business 3 (3): 1332-1338.

Acee, T. W., et al. 2010. "Academic boredom in under- and overchallenging situations". Contemporary Educational Psychology 35 (1): 17-27.

Adorno, T. W., Horkheimer, M. 1997. Dialectic of Enlightenment. London: Verso.

Ahmed, S. M. S. 1990. "Psychometric properties of the boredom proneness scale". Perceptual and Motor Skills 71: 963-966.

Alexandria, C. 1964. "Zeno et Zenonis discipuli". In Arnim, H. V. Stoicorum Veterum Fragmenta (SVF). 1. Stuttgart: Teubner.

Anderson, B. 2004. "Time-Stilled Space-Slowed: How Boredom

7. Aknowledgements: This work was supported by the Spanish Ministry of Education, Culture and Sports [FPU12/01877].

Thémata. Revista de Filosofía $\mathrm{N}^{\circ} 56$ (2017) pp.: 171-198. 
Matters". Geoforum 35 (6): 739-754.

Antón, M. C. 2012. "El aburrimiento". Perspectivas en Psicología 9: 104-109.

Aquinas, S. T. 2007. Summa Theologica. New York: Cosimo.

Artino, A. R., Stephens, J. M. 2007. "Cognitive antecedents of boredom and frustration". Academic Exchange Quarterly, 11 (4): 17.

Augustine, S. 2006. Augustine Confessions. Cambridge: Hackett.

Bailey, C. 1947. Titi Lucreli Cari De rerum natura libri sex. Oxford: OUP.

Barbalet, J.M. 1999. "Boredom and social meaning". British Journal of Sociology 50: 631-646.

Bargdill, R. W. 1998. Being bored with one's life: An empirical phenomenological study, UMI Company. PhD diss., Duquesne University. 2000. "A phenomenological investigation of being bored with life". Psychological Reports 86: 493-494.

Barnett, L. A. 2005. "Measuring the ABCs of leisure experience. Awareness, boredom. Challenge, Distress". Leisure Sciences 27 (2): 131-155.

Baudelaire, C. 1983. Les Fleurs du Mal. New Hampshire: David R. Godine.

Benjamin, W. 1999. The Arcades Project. Harvard: HUP.

Bergler, E. 1945. "On the disease-entity boredom ("alyosis") and its psychopathology". Psychiatric Quarterly 19 (1): 38-51.

Bergstein, A. 2009. "On Boredom: A close encounter with encapsulated parts of the psyche". International Journal of Psychoanalysis 90: 613-631.

Bigelow, P. 1983. "The ontology of boredom: A philosophical essay". Man and World 16 (3): 251-265.

Bills, M. 2003. "Boredom in the experience economy". Display \& Design Ideas 15 (10): 66.

Bilz, R. 1971. "Langeweile. Versuch einer systematischen Darstellung". In Paläo-anthropologie: Der neue Mensch in der Sicht der Verhaltensforschung. FaM: Suhrkamp, 241-276.

Binnema, D. 2004. "Interrelations of psychiatric patient experiences of boredom and mental health". Issues in mental health nursing 25 (8): 833-842. Suhrkamp.

Blumenberg, H. 2006. Beschreibung des Menschen. FaM:

--- 2011. Descripción del ser humano. México: FCE.

Bolland, S., Emami, S. 2007. "The benefits of boredom: An exploration in developmental robotics". IEEE-ALife'07, 1-5 April, Honolulu.

Bromberg, J. 1981. "Retirement: Boredom or bliss". Aging 317: 17-21.

Bruursema, K. 2007. How individual values and trait boredom interface with job characteristics and job boredom in their effects on 
counterproductive work behavior. $\mathrm{PhD}$ diss., University of South Florida. Büchner, G. 1998. Danton's Death; Leonce and Lena; Woyzeck. Oxford: OUP.

--- 1996. Dantons Tod and Woyseck. Manchester: MUP.

--- 2006. Complete Plays, Lenz and Other Writings. London: Penguin.

Butler, N. 2011. "Work, play and boredom". Ephemera 11 (4): 329-335.

Byor, T. V. 1975. "Do Spokesmen Commercials Portend an Era of Boredom in TV Advertising?". Advertising Age: 35.

Byron, G. G. 1852. Don Juan. London: A. Cunningham.

Campbell, R. N. 1996. Psychiatric Dictionary. New York: OUP.

Cassian, J. 2000. The institutes. New York: Newman.

Charlton, B. G. 2008. "Crick's gossip test and Watson's boredom principle: A pseudo-mathematical analysis of effort in scientific research". Medical hypotheses 70 (1): 1-3.

Chateaubriand, F. R. D. 2014. Memoirs from Beyond the Tomb. London: Penguin.

Cioran, E. 1987. History and Utopia. New York: Seaver.

Clive, G. 1965. "A phenomenology of boredom". Journal of existentialism 5 (20): 359.

Cronon, W. 2012. "Professional Boredom". Perspectives on History March: 6-7.

Conrad, P. 1997. "It's Boring: Notes on the Meanings of Boredom in Everyday Life". Qualitative Sociology 20 (4): 465-475.

Damasio, A. R. 1999. The Feeling of Waht Happens: Body and Emotion in the Making of Consciousness. New York: Harcourt Brace \& Co.

--- 2003. Looking for Spinoza: Joy, Sorrow, and the Feeling Brain. North Eugene: Harvest.

Damrad-Frye, R., Laird, J. D. 1989. "The experience of boredom: The role of the self-perception of attention". Journal of Personality and Social Psychology 57 (2): 315.

Danckert, J. A., Allman, A. A. 2005. "Time flies when you're having fun: Temporal estimation and the experience of boredom". Brain and Cognition 59 (3): 236-245.

De Chenne, T. K. 1988. "Boredom as a clinical issue". Psychotherapy: Theory, Research, Practice, Training 25: 71-81.

Deleuze, G. 1995. Negotiations 1972-1990. New York: CUP.

Donne, J. 1899. The life and letters of John Donne. London: Heinemann.

Dostoievski, F. 1881. Prision Life in Siberia. New York: Harper and Brothers.

--- 1918. The Novels of Fyodor Dostoevsky: White nights. 
Portsmouth: Heinemann.

--- 1923. The gambler: And Other Stories. New York: MacMillan

--- 1956. Crime and Punishment. New York: Random.

--- 1999. Notes from the Underground. Oxford: OUP.

Durkheim, E. 1997. The Division of Labour in Society. London: Simon and Schuster.

--- 2006. On Suicide. London: Penguin.

Dym, B., Glenn, M. L. 1994. Liebe, Lust und Langeweile: die Zyklen intimer Paarbeziehungen. München: Dtv.

Eastwood, J. D., Frischen, A., Fenske, M. J., Smilek, D. 2012. "The unengaged mind defining boredom in terms of attention". Perspectives on Psychological Science 7 (5): 482-495.

Euripides. 1782. The nineteenth tragedies and fragments of Euripides. London: Nichols and Payne.

Fahmy, N. R. M., Noble, J. 1981. "Digital osteomyelitis due to boredom". The Hand 3: 285-286.

Farmer, R., Sundberg, N. D. 1986. "Boredom proneness: The development and correlates of a new scale". Journal of Personality Assessment 50: 4-17.

Fenichel, O. 1951. "On the psychology of boredom". In Organization and pathology of thought, ed. Rappaport, D. 349-361. New York: CUP.

Fisher, C. D. 1987. Boredom: construct, causes and consequences. Texas: A\&M.

--- 1991. "Boredom at work: A neglected concept". Human Relations 46 (3): 395-417.

Flaubert, G. 2014. Madame Bovary. Paris: Arvensa.

Fontane, T. 1976. Jenny Treibel. New York: F. Ungar.

--- 2012. Effi Briest. Kansas: Neeland.

--- 2015. Trials and Tribulations. New York: Mondial.

German, D., Latkin, C. A. 2012. "Boredom, depressive symptoms, and HIV risk behaviors among urban injection drug users". AIDS Behaviour 16 (8): 2244-2250.

Goethe, J. W. V. 1988. The Sorrows of Young Werther; Elective Affinities; Novella. Princeton: PUP.

-- 1987. From my life. FaM: Suhrkamp.

-- 1840. "Campagne in Frankreich". In: Sämmtliche Werke. Paris: Baudry's, 65-128.

--- 1841. "Sonette XV". In: Feldbausch, F. S. Deutsche Metrik. Heidelberg: Karl Winter.

--- 1859. Götz von Berlichingen mit der eisern Hand. Stuttgart: J. G. Cotta 'scher.

--- 1909. "Schriften zur Naturwissenschaft”. In: Sämtliche Werke. 
Berlin: Propyläen, 444-517.

--- 1970. Italian Journey. London: Penguin.

Goffman, E. 1959. The Presentation of Self in Everyday Life. London: Penguin.

Gombrich, E. H. 1999. "The pleasures of boredom". In The uses of images: studies in the social function of art and visual communication. London: Phaidon, 212-225.

Hamilton, P. 1999. "Boredom-reducing feeding device for caged animals". U. S. Patent 5: 815-894.

Hancock, P. A., Krueger, G. P. 2010. Hours of boredom, moments of terror: Temporal desynchrony in military and security force operations. Washington: National Defense University.

Harrison, A. 1984. "Creativity, class, and boredom: Cognitive models for intelligent activities". Journal of Education 166 (2): 150-169. Healy, S. D. 1984. Boredom, Self and Culture. New Jersey: Fairleigh Dickinson UP.

Heidegger, M. 1995. The Fundamental Concepts of Metaphysics: World, Finitude, Solitude. Indiana: IUP.

Heine, H. 1872. Französische Zustände. Hamburg: Hoffmann und Campe.

--- 1874. Book of Songs. New York: Henry Holt.

Hölderlin, F. 2008. The Death of Empedocles. New York: Suny Press.

Homer. 1813. Iliad. London: St. Paul's Church Yard.

Hopkins, V. D. 1980. "Boredom". The Controller 19 (1): 6-10.

Horace. 1872. The Epistles and Art of Poetry of Horace. Edinbugh: Nimmo.

Ibsen, H. 1995. Peer Gynt. A Dramatic Poem. Oslo: SUP.

--- 2002. Hedda Gabler. New York: Dramatists Play Service.

Inman, A., Kirsh, K. L., Passik, S. D. 2003. "A pilot study to examine the relationship between boredom and spirituality in cancer patients". Palliative \& supportive care 1(2): 143-151.

Iso-Ahola, S. E., Weissinger, E. 1987. "Leisure and boredom". Journal of Social and Clinical Psychology 5: 356-364.

Kafka, F. 1949. The Diaries of Franz Kafka. 1914-1923. London: Secker and Warburg.

Kant, I. 2012. Anthropology from a Pragmatic Point of View. Berlin: Springer.

Kass, S. J., Vodanovich, S. J., Callender, A. 2001. "State-trait boredom: Relationship to absenteeism, tenure, and job satisfaction". Journal of Business and Psychology 16: 317-327.

Kleist, H. V. 1826. Gesammelte Schriften. Berlin: Ludwig Tieck. 
Kierkegaard, S. 2004. Either/Or. London: Penguin.

--- 2009. Repetition and Philosophical Crumbs. Oxford: OUP.

--- 2013. Kierkegaard's Writings, XIX: Sickness Unto Death: A Christian Psychological Exposition for Upbilding and Awakening / II: The concept of Irony, with Continual Reference to Socrates / Notes of Schelling's Berlin Lectures. Princeton: PUP.

Köster, E. P., Mojet, J., and MacFie, H. 2007. "Boredom and the reasons why some new food products fail". Consumer-led food product development: 262-280.

Kracauer, S. 1995. The Mass Ornament: Weimar Essays. Cambridge: HUP.

Kreisel, D. K. 2006. "Wolf Children and Automata: Bestiality and Boredom at Home and Abroad". Representations 96 (1): 21-47.

Kuhn, R. C. 1976. The Demon of Noontide: Ennui in Western Literature. Princeton: PUP.

Lee, Y., Mittelstaedt, R., Askins, J. 1999. "Predicting free time boredom of people with spinal cord injury". Therapeutic Recreation Journal 33: 122-134.

Leong, F. T., Schneller, G. R. 1993. "Boredom proneness: Temperamental and cognitive components". Personality and Individual Differences 14: 233-239.

Leslie, I. I. 2009. "From idleness to boredom: on the historical development of modern boredom”. Critical Studies 31 (1): 35-59.

Leung, L. 2008. "Leisure boredom, sensation seeking, self-esteem, and addiction". Mediated interpersolal communication, 359-381.

Liddell, H., Scott, R. Jones, H. S. 1940. Greek-English Lexicon. Oxford: Clarendon.

Lipps, T. 1909. Leitfaden der Psychologie. Leipzig: Wilhelm Engelmann.

London, H., Monell, L. 1974. Thought and feeling. Chicago: Aldine. Loyola, St. I. 2007. The Spiritual Exercises of St. Ignatius of Loyola. New York: Cosimo.

MacDonald, D. A., Holland, D. 2002. "Spirituality and boredom proneness". Personality and Individual Differences 32: 1113-1119.

Mains, D. 2007. "Neoliberal times: progress, boredom, and shame among young men in urban Ethiopia". American Ethnologist 34 (4): 659-673.

Mallarmé, S. Coffey, B. 1990. Poems of Mallarmé. London: Menard.

Mallory, A. 2003. "Burke, Boredom, and the Theater of Counterrevolution". Publications of the Modern Language Association of America: 224-238.

Mann, T. 1996. The Magic Mountain. New York: Random.

-.- 1997. Little Herr Friedemann and Other Stories. London: 
Minerva.

--- 2011. Buddenbrooks. New York: Knopf Doubleday.

--- 2013. Royal Highness. New York: Knopf Doubleday.

Martin, M., Sadlo, G., Stew, G. 2006. "The phenomenon of boredom". Qualitative Research in Psychology 3: 193-211.

Merrifield, C. 2014. Toward a Model of Boredom: Investigating the Psychophysiological, Cognitive, and Neural Correlates of Boredom. PhD diss., University of Waterloo.

Montaigne, M. D. 2009. Les essais. Paris: Pocket.

Munsterberg, H. 1913. Psychology and industrial efficiency. Boston: Houghton-Miffin.

Musharbash, Y. 2007. "Boredom, time, and modernity: An example from Aboriginal Australia". American Anthropologist 109 (2): 307-317.

Musil, R. 2014. The Confusions of Young Törless. Oxford: OUP.

Nett, U. E., Goetz, T., Daniels, L. M. 2010. "What to do when feeling bored?: Students' strategies for coping with boredom". Learning and Individual Differences 20 (6): 626-638.

Nett, U. E., Goetz, T., Hall, N. C. 2011. "Coping with boredom in school: An experience sampling perspective". Contemporary Educational Psychology 36 (1): 49-59.

Nietzsche, F. (1896). Werke. Berlin: Colli/Montinari.

Nietzsche, F. 2001. The Gay Science. Cambridge: CUP.

--- 2005. The Anti-Christ. New York: Cosimo Classics.

Novalis. 1992. Hymns to the Night; Spiritual Songs. Forest Row: Temple Lodge.

Núñez, P. S. 2000. "El gran ennui o la monotonía de lo insignificante: sexualidad, dispositivo femenino y aburrimiento". Espéculo 14: 1139-3637.

O'Farrell, P. 1982. "Boredom as historical motivation". Quadrant 26 (12): 52 .

O'Hanlon, J. E. 1981. "Boredom: Practical consequences and a theory". Acta Psychologies 49: 53-82.

Ohlendorf, V. 2012. Grenzenloser Spaß oder endlose Langeweile?: Sexualität in der Erlebnisgesellschaft. München: GRIN.

Parreño, R. 2013. "Aburrimiento y Espacio: Experiencia, Modernidad e Historia". Revista de la Escuela de Arquitectura de la Universidad de Costa Rica 2, 3: 1-15.

Pascal, B. 2007. Thoughts, Letters, and Minor Works. New York: Cosimo.

Passik, S. D. 2003. "Boredom as a component of distress in advanced cancer patients". Psycho-Oncology 12 (4): 227.

Pekrun, R., Goetz, T., Daniels, I. M., Stupnisky, R. H., Perry, R. P. 2010. "Boredom in achievement settings: Exploring control-value antecedents 
and performance outcomes of a neglected emotion". Journal of Educational Psycbology 102 (3): 531-549.

Perkins, R. E. 1981. The nature and origins of boredom. PhD diss., University of Keele.

Pessoa, F. 2010. The Book of Disquiet. London: Profile Books.

Peters, E. 1975. "Notes toward an archaeology of boredom". Social Research 42: 493-511.

Philippson, R. 1943. "Papyrus Herculanensis 831". The American Journal of Philology 64 (2): 148-162.

Pindar. 1962. Phytian Odes. Oxford: OUP.

Plato. 1997. Complete works. Cambridge: Hackett.

--- 2010. Plato's Protagoras. Translation, Comentary and Appendices. New York: Rowman \& Littlefield.

Priest, E. 2011. "Listening to Nothing in Particular: Boredom and Contemporary Experimental Music". Postmodern Culture 21 (2).

Rakoff, J. 2001. "E-boredom”. University Business 4 (3): 16.

Raposa, M. 1999. Boredom and the Religious Imagination. Charlottesville: University Press of Virginia.

Retana, C. 2011. "Consideraciones acerca del aburrimiento como emoción moral". Káñina, Revista de Artes y Letras, Universidad de Costa Rica 35 (2): 179-190.

Revers, W. J. 1949. Die Psychologie der Langeweile. Meisenheim am Glan: Hain.

Rousseau, J. J. 1776. Émile, ou de l'education. La Haya: Chez Jean Néaulme.

Rubin, L. 2009. "The Politics of Boredom: Punk, the Situationist International and Chuck Palahniuk's Rant". Reading Chuck Palahniuk: American Monsters and Literary Mayhem: 129-142.

Russell, B. 1930. The Conquest of Hapiness. London: Allen \& Unwin.

Sartre, J. P. 1957. The Transcendence of the Ego. New York: Farrar, Straus, and Giroux.

Seneca. 1786. Moral Letters to Licilius. Toronto: Aegitas.

Schiller, F. 1805. Theater: Die Huldigung der Künste. Don Karlos. Die Jungfrau von Orleans. Tübingen: J. G. Cotta'sche.

--- 2008. Fiesco Or the Genoese Conspiracy. Carolina: BiblioBazaar.

Schopenhauer, A. 1895. Zur Philosophie und Wissenschaft der Natur. In: Sämtliche Werke in zwölf Bänden. Stuttgart, Berlin: J. G. Cotta'sche, 103178. Courier.

--- 2006. Parerga and Paralipomena. Madrid: Trotta.

--- 2012. The World as Will and Representation. Massachusetts:

Scitovsky, T. 2000. "The wages of boredom”. New Perspectives Quarterly 
17 (2): $45-51$.

Sibayan, J. F. 2000. "Art and Boredom". IDEYA: Journal of the Humanities 1 (2): 88-98.

Simmel, G. 1892. Einleitung in die Moralwissenschaft: Eine Kritik der ethischen Grundbegriffe. Berlin: Hertz.

--- 2011. The Philosophy of Money. Oxford: Francis \& Tylor.

Smith, R. P. 1981. "Boredom: A Review". Human Factors 23: 329-340.

Solomon. 1831. A new translation of the Proverbs of Solomon. Cambridge: CUP.

Sommers, J., Vodanovich, S. J. 2000. "Boredom Proneness: Its Relationship to Psychological- and Physical-Health Symptoms". Journal of Clinical Psychology 56 (1): 149-155.

Stagner, R. 1975. "Boredom on the assembly line: Age and personality variables". Industrial Gerontology 2: 23-44.

Strahan, J. C. 1980. "The retired patient: boredom, fears, and suicide". Delaware medical journal 52 (9): 497-501.

Strindberg, A. 1912. Samlade skrifter: Röda Rummet. Stockholm: Albert Bonniers.

--- 1951. Skrifter av August Strindberg: Hemsöborna. Skärkarlsliv. Stockholm: Albert Bonniers.

--- 2013. Married. Auckland: Floating.

Svendsen, L. 2005. A Philosophy of Boredom. London: Reaction.

Tardieu, E. 1913. L'ennui: Étude psychologique. Paris: Libraire Félix Alcan.

Theobald, D. E., et al. 2003. "An open label pilot study of citalopram for depression and boredom in ambulatory cancer patients". Palliative \& supportive care 1 (1): 71-77.

Todman, M. 2003. "Boredom and psychotic disorders: Cognitive and motivational issues". Psychiatry 66 (2): 146-167.

Tolstói, L. 1920. War and Peace. New York: MacMillan.

--- 1995. Anna Karenina. Hertfordshire: Wordsworth.

--- 2004. "The Kreutzer Sonata". In: The Death of Ivan Ilyich \& Other Stories. Hertfordshire: Wordsworth, 131-199.

--- 2005. Family Happiness and Other Stories. New York: Dover.

--- 2007. The kingdom of God is within you. Charleston: BiblioBazaar.

--- 2010. The Death of Ivan Ilych and Other Stories. London: Vintage.

--- 2011. Resurrection. Auckland: Floating.

Toohey, P. 1988. "Some Ancient Notions of Boredom". Illinois Classical Studies 13 (1): 151-164.

--- 2011. Boredom. A Lively History. New Haven: YUP.

Tucker, B. 2007. "Performing Boredom in Effi Briest: On the Effects of Narrative Speed". The German Quarterly 80 (2): 185-200. 
Unamuno, M. 1928. Mist. Illnois: IUP.

Valéry, P. 1988. Mon Faust. Paris: Gallimard.

--- 1951. Dance and the Soul. London: John Lehmann.

--- 1957. Euvres, I. Paris: Gallimard.

Van Tilburg, W. A. P., Igou, E. R. 2011. "On boredom: Lack of challenge and meaning as distinct boredom experiences". Motivation and Emotion 36 (2): 181-194.

Verlaine, P. 2003. The Crused Poets. Los Angeles: Green Integer.

--- 2013. Songs without Words. Oakland: Omnidawn.

Vodanovich, S. J. 2003. "Psychometrics measure of boredom: a review of the literature". The Journal of Psychology 137 (6): 569-595.

Vodanovich, S. J., Watt, J. D. 1999. "The relationship between time structure and boredom proneness: An investigation within two cultures". The Journal of social psychology 139 (2): 143-152.

Vogel-Walcutt, J. J. 2012. "The Definition, Assessment, and Mitigation of State Boredom Within Educational Settings: A Comprehensive Review". Educational Psychology Review 24 (1): 89-111.

Völker, L. 1975. Langeweile. Munich: Fink.

Voltaire. 1927. The Age of Louis XIV. London: J. M. Dent \& Sons.

Weinberg, K. 1984. "The Women of Eliot and Baudelaire: The Boredom, the Horror and the Glory". Modern Language Studies: 31-42.

Wemelsfelder, F. 1993. Animal Boredom, Towards an Empirical Approach of Animal Subjectivity. PhD diss., the Netherlands, University of Leiden.

Wordsworth, W., Coleridge, S. T. 1798. Lyricall Ballads. London: J. \& A. Arch.

Yamamoto, N., Ishikawa, M. 2010. "Curiosity and boredom based on prediction error as novel internal rewards". Brain-Inspired Information Technology. Studies in Computational Intelligence 266: 51-55. 